\title{
E-WOM attractiveness, e-brand community trust, e-brand community experience and brand loyalty: a study on XIAOMI electronic brand community in Indonesia
}

\author{
Elia Ardyan \\ Management Department, Sekolah Tinggi Ilmu Ekonomi Surakarta, Indonesia \\ Diponegoro University, Indonesia \\ Berta Bekti Retnawati \\ Faculty of Economics and Business, Soegijopranata Chatolic University, Indonesia \\ Naili Farida \\ Diponegoro University, Indonesia
}

\begin{abstract}
Keywords
e-WOM Attractiveness, e-Brand Community Trust, e-Brand Community Experience and Brand Loyalty
\end{abstract}

\begin{abstract}
This study discusses electronic brand community (e-brand community), especially Xiaomi online community in Indonesia. The goals of this research are (1) to analyse the influence of e-WOM attractiveness on e-brand community trust, (2) to analyse the Influence of e-brand community experience on e-brand community trust and brand loyalty, (3) to analyse e-brand community trust on brand loyalty. The research samples are 139 members of Xiaomi online community in Indonesia. The analysis used in this study is a structural equation modelling (SEM) with AMOS version 21 to process the data. The results show that only e-brand community experience is able to improve brand loyalty. E-WOM attractiveness is unable to improve e-brand community trust. Other results show that e-brand community experience has negative and insignificant influence on e-brand community trust, while e-brand community trust has positive but insignificant influence on brand loyalty. The research implications are: first, focus on building website in which there is an interactive forum. Second, strive to build an active participation of online community members. Third, as an effort for e-WOM attractiveness to raise online community members' trust, the company needs to actively engage in any opinions made by the leaders of renowned 'figures' in community members and be actively involved in communication with this product communities.
\end{abstract}

Corresponding author: Elia Ardyan

Email addresses for corresponding author: Ardyan.Sbs@Gmail.Com

First submission received: $26^{\text {th }}$ August 2017

Revised submission received: $24^{\text {th }}$ October 2017

Accepted: $2^{\text {nd }}$ November 2017

\section{Introduction}

Indonesia has very high potential in the development of online community. In 2014, the data show that the Indonesian population is about 252 million people. From such number, approximately 88.1 million people have been using internet media in their daily life (AAJII, 2015). Although the number of internet users is high, however, only $4.3 \%$ of them use internet for online community.

Brand community is the relation network between parent brand and its members (Samu et al., 2012). Community tends to be identified based on similarity or identification of members, whether environment, occupation, time killing or devotion to brand (McAlexander et al., 2002). Members feel connected each other (Bagozzi \& Dholakia, 2006b). The advantage of brand community is to facilitate information sharing, to strengthen brand history and culture, to assist consumers, and to influence brand loyalty positively (Muniz \& O'guinn, 2001).

Marketer should start learning how to organize and manage virtual community (Bagozzi \& Dholakia, 2002). In Indonesia, online community tends to use social network (Facebook \& twitter), blog, 
and website. Online community encourages its members sharing spirit among members of a common value system to unite their social and psychological needs through mutual commitment to and sense of belonging to the subscribed community (Petrovčič et al., 2016). There is sense of unity mutually perceived by online community members in addition to the sense of belonging. Blanchard (2008) confirms the existence of group identity, mutually beneficial influence one to another, and perceived common experience. Online group members tend to be committed to their community which is made as long-term active participation, cooperative collaboration, mutual support, as a form of norms of reciprocity which generates mutual trust.

One method to build online community (e-brand community) is by creating trust among community members. Trust is a very important thing in online community (Luo \& Zhang, 2016). Basically, trust in online media may be built through security, time limitedness, accuracy (Tanrikulu \& Celilbatur, 2013), past experience (Ha \& Perks, 2005; Sahin et al., 2011), etc. Trust in online community may increase engagement (Hsu et al., 2012), create commitment (Morgan \& Hunt, 1994), build loyalty (Singh \& Sirdeshmukh, 2000), and brand equity (Chaudhuri \& Holbrook, 2001).

The problem of this research is how to create e-WOM attractiveness and e-brand community experience in order to improve brand trust and loyalty. The goals of this research are: First, to analyse the influence of e-WOM attractiveness on E-brand community trust. Second, to analyse the influence of ebrand community experience on e-brand community trust and brand loyalty. Third, to analyse e-brand community trust on brand loyalty.

\section{Literature review}

\subsection{E-Brand Community}

Fuller et al. (2007) define online based community as virtual setting based brand community in which the members interact using internet media. Online brand community is also defined as a group of consumers that gather and interact online in order to achieve personal or mutual goals. The type of this community is different from traditional community (Albert et al., 2008). Lin (2007) explains that online community uses internet as the ground of connecting, thus physical contact is no longer relevant. This makes the participants of online community are mostly invisible. The cost incurred is also cheaper than that of traditional community.

In some literatures, the use of internet to build community is often called online based community (Brogi, 2014;Fuller et al., 2007). Such community often uses social media, for example Facebook, twitter or virtual community (Bagozzi \& Dholakia, 2002;Shang et al., 2006Wang et al., 2015). Facebook brand community covers the following features: sharing company, product or information service, communicating and sharing marketing messages, expanding network, and receiving feed-back update (Hsu, 2012) and sharing enthusiasm in using product (de Vries et al., 2012). Compared to offline traditional brand community, it is easier and cheaper for a company to develop online brand community (Cova \& Pace, 2006). Activities in online community may improve the purchase frequency (Wu et al., 2015).

\section{2. e-WOM attractiveness}

In marketing literature, we have word of mouth (WOM) concept. WOM is a form of betweenfriends or interpersonal non-commercial communication in which an individual tells various positive things of brand to other parties. Now, WOM develops to electronics word of mouth (e-WOM) (Cheung \& Thadani, 2010). E-WOM refers to positive or negative statement made by potential, actual and former customers of a product or company via internet (Hennig-Thurau et al., 2004). One of the forms of e-WOM is issuing opinion of a brand in online media or internet such as website, blog, discussion forum, social media, etc. (Cheung \& Thadani, 2010).

In this research, we define e-WOM attractiveness as positive characteristic in relation to information shared by consumers related to certain brand or product. The focus of this study is to observe the characteristics of e-WOM. The interesting characteristics of e-WOM include: complete comment, clear information, transparent information, open to all opinions (Wu et al., 2015). Complete comment means that the given information is intact. Clear information means that any individual who receives it understands such information. Transparent information means that informant does not conceal any 
negative information of certain brand or product. Open to opinion means that the given information is always open to other's critics of such information.

\section{3. e-Brand Community Experience}

Experience concept is used in online context. In 2005, Ha and Perks (2005) see brand experience by focusing on web brand experience. Other various researches also analyse the use of experience in online sale and purchase context (Lin, 2015;Obada, 2014). Many experts also explain experience in the context of online community (Nambisan \& Watt, 2011;Wang et al., 2015;Wu et al., 2015). In brand online community, one method to obtain experience is to participate in such electronic brand community (Bagozzi \& Dholakia, 2006b; Wu et al., 2015). Participation means taking part in presenting opinion any other activities which may provide added value to such e-brand community. Nambisan and Watt (2011) explain that there are some dimensions of e-brand community, such as usability experience, hedonic experience, sociability experience.

\section{4. e-Brand Community Trust}

Trust is the centre of online environment (Gommans et al., 2001; Tanrikulu \& Celilbatur, 2013), one of the methods is to utilize trust on e-commerce (Corbitt et al., 2003). Trust may provide stimulus to buy via internet (Mukherjee \& Nath, 2007). Trust in online environment also reduces perception of uncertainty and risk, and influences other behaviours such as information sharing (McKnight et al., 2002). Initially, trust tends to occur between men (Solomon \& Flores, 2001). However, in online/ e-commerce environment, people can trust tools or attributes in online environment. Gommans et al. (2001) state that in online environment in general, we cannot feel, touch and see salespeople. Trust in online environment arises when an individual has good experience while using internet, design website, information, country of origin, testimony, and security (Ha, 2004; Ruparelia et al., 2010).

\subsection{Brand Loyalty}

Loyalty is considered as an important part of a company since loyalty will affect long-term profit (Ribbink et al., 2004). Loyalty is one of the most desired factors of a company. Loyalty enables a company to become more efficient. This is because the cost to make people loyal is lower than to find new customers. Loyalty is defined differently. First, loyalty is identical to commitment to repeat order. Loyalty is also a strong commitment to repurchase product and service consistently in the future, where such purchase is made to the same brand (Oliver, 1999). Second, Loyalty is not merely a commitment, but it is an act to repurchase. Brand loyalty generally refers to repeat order made by consumer (Shang et al., 2006).

\section{Hypotheses Development}

\subsection{The Impacts of E-WOM on e-Brand Community and e-Brand Community Trust}

Internet has become one of the most important communication. People can easily write their feeling and experience through website, blog, or other social media. E-WOM is one of important things in the field of E-Commerce. When someone wants to buy product or service, he or she usually gains the information from the internet. In the context of online community, the consumers incline to believe those who have written on certain community's website. This is caused by the inclination of the members of online community to present information based on the fact. The literature research which examines the impacts of e-WOM on e-brad brand community trust insists that there is one direction relation, and the intrinsic motivation will encourage someone to conduct e-WOM. The participation of the customers' review will give impacts in building an identification of the website and will give great impacts to the trust community toward the retailer (Yoo et al., 2013). In the same way, the result of Jeong and Koo (2015) research proves that the community's positive reviews which are subjective or objective, will give impacts on the trust toward the product and willingness to find the offered product in the community. That is why we propose the first hypothesis as follows:

H1: E-WOM in e-brand community have positive effect on E-brand Community trust

\subsection{The Impacts of e-Brand Community Experience on e-Brand Community Trust}

In the context of online community, Brogi (2014) explain that online brand community is related with the interaction between the members. The interaction will create certain experience for the members of the online community. Some of other experiences are: Usability Experience, Hedonic Experience, and 
Sociability Experience (Nambisan \& Watt, 2011). Chen et al. (2009) explain about customer to customer (C2C) platform, that one of trust antecendent of online community is social interaction. The socialization experience between the members will be able to strengthen the brand's trust which has the need of socialization is as important experience for the online community members. Thus, we propose second hypothesis as follows:

H2: E-brand community experience have positive effect on Brand Community Trust.

\subsection{The Impacts of e-Brand Community Experience on Brand Loyalty}

One of the experiences of the online community's members is the existence of communication between the members discussing the community. The communication will influence the preference on the brand and he decision of purchasing (Bickart \& Schindler, 2001). The intensive communication needs much of time and effort. We often communicate with other members every day. Iwasaki and Havitz (1998) suggest that the time and effort given during the participation in the community is a sunk cost that will cause the commitment on the brand and its loyalty.

McMillan and Chavis (1986) use a term called "sense of community" to explain the experience of the community's members. Sense of community is identified as members' feeling of belonging and being important to each other, and a shared faith that the members' needs will be met by the commitment to be together (McMillan \& Chavis, 1986). The manager must be able to measure the degree of the sense of community (Blanchard, 2008) because the sense of community can increase the loyalty of community members (Keng et al., 2011). Therefore, we propose the third hypothesis as follows:

H3: E-brand community experience have positive effect on brand loyalty.

\subsection{The Impacts e-Brand Community Trust on Brand Loyalty}

Basically, trust will precede the consumers' loyalty (Harris \& Goode, 2004). The brand loyalty as an important consequence of the brand trust has been conceptualized as the motive of attitude or as the true pattern of purchasing action, or both of them (Matzler et al., 2008). Some other researchers also explain that trust can increase the loyalty (Chaudhuri \& Holbrook, 2001; Gommans et al., 2001; Harris \& Goode, 2004; Sahin et al., 2011; Singh \& Sirdeshmukh, 2000). Brand Trust has a very important role for creating commitment (Morgan \& Hunt, 1994), build loyalty (Singh \& Sirdeshmukh, 2000), and brand equity (Chaudhuri \& Holbrook, 2001). In the research conducted by Chaudhuri and Holbrook (2001) and Matzler et al. (2008) find that the brand trust will positively and significantly influence on the attitude and repurchase loyalty.

H4: E-brand community trust have positive effect on brand loyalty.

\section{Research Method}

\subsection{Sample}

This research was conducted by questionnaires - both online and off online questionnaires. From 250 questionnaires shared to the members of Xiaomi community, there were only 197 questionnaires which returned. From the 197 questionnaires, after their normality as data is analyzed, there were only 139 which had normal data. Therefore, there were only 139 respondents whose data can be used for the following analysis. Hair et al. (2010) explain the allowed minimal standard of the sample. If the construct used less than 5 and each construct has minimal indicator in 3, the minimal sample which can be used will be 100. According to Hair et al. (2010), the 139 samples in this research can be used because it pass the minimum requirement.

From the total of 139 respondents, 93 of them were men and 46 respondents were women. The respondents work in various job including: 72 respondents work as private workers, 23 respondents work as governmental officers, 14 respondents work as entrepreneurs, 10 respondents were studying in university, and 20 respondents work in another fields. The average ages of the respondents were around 26 years. The education background of the respondents were 69 respondents with bachelor background, 44 respondents with high school background, and 26 respondents with post graduated background.

\subsection{Measurement}

There were 4 main variables, such as e-WOM, e-brand community experience, e-brand community trust and brand loyalty. The scale of the measurement of each instruments in this research seven point 
Likert scale $(1=$ strongly disagree, $7=$ strongly agree $)$. The following variables and indicators used in this study:

- Indicator of e-WOM in e-brand comunity are e-WOM have complete review, information from eWOM is very effective, all e-WOM information is very transparent, and e-WOM become open for all opinions (Adopted from Wu et al. (2015))

- Indicator of e-brand community experience are sociability experience, usability experience, and hedonic experience (Nambisan \& Watt, 2011)

- Indicator of e-brand community trust are e-brand community reliability, e-brand community responsibility, e-brand community responsibility, and e-brand community competence (DelgadoBallester et al. (2003); Morgan and Hunt (1994))

- Indicator of brand loyalty are recommendation and repurchase (Oliver \& Rust, 1997)

\subsection{Analysis}

In this research, the analysis of Structural Equation Modeling (SEM) was used to analyze the data. SEM is one of statistic models which explain the relation of multiple variables (Hair et al., 2010). There were some examinations conducted in this research, such as: data normality test, validity test, reliability test, goodness of fit test, and hypothesis test. The supporting tool in processing the data used Amos with 21 version.

\section{Results}

\subsection{Validity and Reliability}

The test of reliability in this research used Cronbach Alpha and Composite Reliability. The requirement of composite reliability is above 0.70 (Hair et al., 2010). Chronbach (1951) develops the coefficient alpha which the cutt of from Cronbach alpha must be above 0.60. Table 1 shows the value of cronbach alpha and composite reliability. Each variable has been reliable because the value is above the requirement.

The test of validity in this research can be seen from the value of loading factor and AVE. Cut off loading factor and AVE is greater than 0.5 (Fornell \& Larcker, 1981). Table 1 describes the valid data because all the value of loading factor and AVE have been above the requirement.

Table 1. Output of Reliability and Validity

\begin{tabular}{|l|c|c|c|c|}
\hline & $\begin{array}{c}\text { Cronbach } \\
\text { Alpha }\end{array}$ & $\begin{array}{c}\text { Composite } \\
\text { Reliability }\end{array}$ & $\begin{array}{c}\text { Loading } \\
\text { Factor }\end{array}$ & AVE \\
\hline E-WOM Attractiveness & 0.946 & 0.946 & 0.921 & \\
- Complete Review & & & 0.815 \\
- Trief Information & & & 0.903 & \\
- Being open for all opinions & & & 0.902 & \\
\hline E-brand Community Experience & 0.947 & 0.952 & & 0.868 \\
- Usability Experience & & & 0.869 & \\
- Hedonic Experience & & & 0.926 & \\
- Sociability Experience & & & 0.997 & \\
\hline E-brand Community Trust & 0.953 & 0.953 & & 0.836 \\
- E-brand Community reliability & & & 0.922 & \\
- E-brand Community credibility & & & 0.929 & \\
- E-brand Community responsibility & & & 0.912 & \\
- E-brand Community competent & & & 0.896 & \\
\hline Brand Loyalty & 0.904 & 0.904 & & 0.826 \\
- Recommendation & & & 0.891 & \\
- Repurchase & & & 0.926 & \\
\hline
\end{tabular}




\subsection{Goodness of Fit}

Goodness of fit shows if the built model has been fit to the data. This research shows that all indicators of model fit have been appropriate with the criteria $(\mathrm{GFI}=0.909$; NFI=0.960; IFI= 0,983; CFI= 0.983; RMSEA=0,07), so it can be concluded that the built model has been good.

\subsection{Test of Hypothesis}

In this researchpropose 4 hypothesis. The hypothesis must be examined to know the effect between the variables which are examined. Table 2 shows the result of the hypothesis test:

Table 2. The Results of Hypothesis Test

\begin{tabular}{|l|c|c|}
\hline \multicolumn{1}{|c|}{ HIPOTESA } & \multicolumn{2}{c|}{ Result } \\
\hline H1: E-WOM in e-brand Community $\rightarrow$ E-brand Trust & $\begin{array}{c}\mathrm{b}=1.227 ; \\
\mathrm{p}=0.150\end{array}$ & H1 Rejected \\
\hline H2: E-brand community experience $\rightarrow$ E-brand & $\mathrm{b}=-0.711 ;$ & H2 Rejected \\
Community Trust & $\mathrm{p}=0.380$ & \\
\hline H3: E-brand community experience $\rightarrow$ Brand Loyalty & $\mathrm{b}=0.931 ;$ & H3 Accepted \\
& $\mathrm{p}<0.05$ & \\
\hline H4: E-brand Community Trust $\rightarrow$ Brand Loyalty & $\mathrm{b}=0.018 ;$ & H4 Rejected \\
& $\mathrm{p}=0.597$ & \\
\hline
\end{tabular}

\section{Discussion}

First, this study analyses the influence of e-WOM attractiveness on e-brand community trust. More attractive electronic word of mouth (e-WOM) may improve online community members' trust. However, this study finds out that e-WOM attractiveness is unable to improve online community members' trust significantly. This results do not conform to previous researches (Jeong \& Koo, 2015; Yoo et al., 2013a). EWOM explains positive or negative statement made by potential, actual and former customers of a product or company via internet (Hennig-Thurau et al., 2004). Consumers can issue their opinion in online media or internet such as website, blog, discussion forum, social media, etc. (Cheung \& Thadani, 2010). In this study, e-WOM attractiveness means positive characteristic of information shared by community members of Xiaomi brands. There are some possible causes of no significant influence of e-WOM attractiveness on e-brand community trust. First, it is possible because a member does not meet the other and they are lack of interpersonal understanding. It does not matter how well a member talks about a product, the other members will not easily believe it because they do not know each other well.

Second, analysing the influence of e-Brand community experience on e-brand community trust. Ebrand community experience is unable to improve e-brand community trust significantly. Experience should be able to improve trust (Ha \& Perks, 2005; Sahin et al., 2011). There are some possible causes of no significant influence of e-brand community experience on e-brand community trust. First, focus on the concept of e-brand community experience on behavioural experience. In this context, behavioural experience in use is member participation (Bagozzi \& Dholakia, 2006b; Shang et al., 2006; Wang et al., 2015). Participation construct may be more suitable in the context of e-brand community or online community. Second, memorable experience is needed in order to be able to improve member's trust in or loyalty to such product. In addition to being not memorable, it is possible that the member's experience does not reach emotional side. Burnett and Buerkle (2000) explains that socialisation experience consists of two types, being information interaction and emotional interaction. If the experience reaches emotional side, it will improve trust.

Third, the results of this research indicate that e-brand community experience is able to improve customer's loyalty. This results conform to previous researches (Keng et al., 2011; McMillan \& Chavis, 1986). The success of electronics brand community relies on existence of consumer's experience. Chen $e t$ al. (2013) suggest that the success of a virtual brand community relies on its members' response, especially in interaction. Interaction among community members is one form of experience in online community. Basically, active communication in e-brand community will reduce the uncertainty of activity (Adjei et al., 2010). Interaction will make members understand more of the brand (Bagozzi \& Dholakia, 2006a). Experience in interaction will make members more loyal (Chen et al., 2009). Gruen et al. (2005) explain that 
customer to customer interaction affects positively loyalty, profitability, brand equity and financial performance.

Fourth, analysing e-brand community trust on brand loyalty. This research indicates that e-brand community trust affects positively but significantly brand loyalty. Trust should reduce uncertainty and Adjei et al. (2010) believe that reduced uncertainty will affect purchase behaviour, especially loyal behaviour to a brand. Previous researches indicate that trust is an important factor in online environment (Gommans et al., 2001; Tanrikulu \& Celilbatur, 2013), where such trust is able to improve loyalty (Chaudhuri \& Holbrook, 2001; Gommans et al., 2001; Harris \& Goode, 2004; Sahin et al., 2011; Singh \& Sirdeshmukh, 2000).

\section{Conclusion and Implication}

This study proposes an integrated framework to conceptualize the relationship between e-WOM attractiveness, e-brand community trust, e-brand community experience and brand loyalty. The results of this research indicate that only e-brand community experience is able to improve brand loyalty. E-WOM attractiveness is unable to improve e-brand community trust. Other results indicate that e-brand community experience has negative and insignificant influence on e-brand community trust, while ebrand community trust has positive but insignificant influence on brand loyalty.

This study have some implication. Trust becomes the center of online environment (Tanrikulu \& Celilbatur, 2013) in general or in the context of online community. Trust means being credible, reliable, competent and responsible (Delgado-Ballester et al., 2003; Morgan \& Hunt, 1994). In order to be attractive, we need to adjust the appearance of e-WOM thus it can raise its members' trust. First, focus on building website where there is interactive forum. The information therein is not only product promotion information, but also various positive testimonies of the use of product or service. Second, strive to build active participation of online community members. Participation is an experience which will be able to raise brand trust and loyalty. Build emotion based participation. Third, as an effort for e-WOM attractiveness to raise online community members' trust, the company needs to actively engage any opinion leader of renowned 'figures' in member community to be involved actively in communication in this product community.

\section{Limitation and Future research}

There are some limitations in this research: first, this research is limited by geographical context and the sample in use is still narrow. Second, there is no consideration of control variable or mediating variable which may provide other point of view of the existing result of research. Second, there is no consideration of the use of e-brand community media, such as website, forum, social media, and blog. Third, the research is limited only to 1 community.

There are some suggestions for future researches. First, the research should be broader. Research is to be made on an e-brand community renowned worldwide, thus the respondents of the research can be cross-nations. Second, it is to consider the use of control variable, for example, how long the subscription in online community Xiaomi is. Third, it is to use the same model for comparison when using personal website and social media (facebook or twitter). Fourth, it is to research several communities. With the model of this study, we compare the results of several communities. The results will be a suggestion for further community development.

References

AAJII. (2015). Profil pengguna internet Indonesia 2014. Jakarta: Asosiasi Penyelenggara Jasa Internet Indonesia.

Adjei, M. T., Noble, S. M., \& Noble, C. H. (2010). The influence of C2C communications in online brand communities on customer purchase behavior. Journal of the Academy of Marketing Science, 38(5), 634-653.

Bagozzi, R. P., \& Dholakia, U. M. (2002). Intentional social action in virtual communities. Journal of Interactive Marketing, 16(2), 2-21.

Bagozzi, R. P., \& Dholakia, U. M. (2006a). Antecedents and purchase consequences of customer participation in small group brand communities. International Journal of Research in Marketing, 23(1), 45-61.

www.jbrmr.com A Journal of the Academy of Business and Retail Management (ABRM) 
Bagozzi, R. P., \& Dholakia, U. M. (2006b). Open source software user communities: A study of participation in Linux user groups. Management Science, 52(7), 1099-1115.

Bickart, B., \& Schindler, R. M. (2001). Internet forum as influential sources of consumer information. Journal of Interactive Marketing, 15(3), 31-40.

Blanchard, A. L. (2008). Testing a model of sense of virtual community. Computers in Human Behavior, 24(5), 2107-2123.

Brogi, S. (2014). Online brand communities: A Literature review. Procedia-Social and Behavioral Sciences, 109, 385-389.

Burnett, G., \& Buerkle, H. (2000). Information exchange in virtual communities: A typology. Information Research, 5(4).

Chaudhuri, A., \& Holbrook, M. B. (2001). The Chain of Effects From Brand Trust and Brand Affect to Brand Performance: The Role of Brand Loyalty. Journal of Marketing, 65(2), 81-94.

Chen, G.-L., Yang, S.-C., \& Tang, S.-M. (2013). Sense of virtual community and knowledge contribution in a P3 virtual community. Internet Research, 23(1), 4-26.

Chen, J., Zhang, C., \& Xu, Y. (2009). The role of mutual trust in building members' loyalty to a C2C platform provider. International Journal of Electronic Commerce, 14(1), 147-171.

Cheung, C. M. K., \& Thadani, D. R. (2010). The Effectiveness of Electronic Word-of-Mouth Communication: A Literature Analysis. Paper presented at the 23rd Bled eConference, Slovenia.

Chronbach, L. J. (1951). Coefficient Alpha and the Internal Structure of Tests. Psychometrika, 22(3), 297-334.

Corbitt, B. J., Thanasankit, T., \& Yi, H. (2003). Trust and e-commerce: A study of consumer perceptions. Electronic Commerce Research and Applications, 2, 203-215.

Cova, B., \& Pace, S. (2006). Brand community of convenience products: New forms of customer empowerment - The case "my Nutella The Community". European Journal of Marketing, 40(9-10), 1087-1105.

de Vries, L., Gensler, S., \& Leeflang, P. S. H. (2012). Popularity of Brand Posts on Brand Fan Pages: An Investigation of the Effects of Social Media Marketing. Journal of Interactive Marketing, 26(2), 83-91.

Delgado-Ballester, E., Munuera-Aleman, J. L., \& Yague-Guillen, M. J. (2003). Development and Validation of Brand Trust Scale. International Journal of Market Research, 45(1), 35-53.

Fornell, C., \& Larcker, D. F. (1981). Evaluating structural equation models with unobservable variables and measurement error. Journal of Marketing Research, 18(1), 39-50.

Gommans, M., Krishnan, K. S., \& Scheffold, K. B. (2001). From Brand Loyalty to e-Loyalty: a Conceptual Framework. Journal of Economic and Social research, 3(1), 43-58.

Gruen, T. W., Osmonbekov, T., \& Czaplewski, A. J. (2005). How e-communities extend the concept of exchange in marketing: an application of the motivation, opportunity, ability theory Marketing Theory, 5(1), 33-49.

Ha, H.-Y. (2004). Factor Influencing Consumer Perceptions of Brand Trust Online. Journal of Product $\mathcal{E}$ Brand Management, 13(5), 329-342.

Ha, H.-Y., \& Perks, H. (2005). Effect of Consumer Perceptions of Brand Experience on The Web: Brand Familiarity, Satisfaction, and Brand Trust. Journal of Consumer Behavior, 4(6), 438-452.

Hair, J. F., Black, W. C., Babin, B. J., \& Anderson, R. E. (2010). Multivariate data analysis (7 ed.). New York: A Global Perspective.

Harris, L. C., \& Goode, M. M. H. (2004). The Four of Loyalty and The Pivitol Role of Trust: A Study of Online Service Dynamics. Journal of Retailing, 80, 139-158.

Hennig-Thurau, T., Gwinner, K. P., Walsh, G., \& Gremler, D. D. (2004). Electronic word of mouth via consumer opinion platforms: What motivates consumers to articulate themselves on the internet? Journal of Interactive Marketing, 18, 38-52.

Ho, C.-W. (2015). Identify with community or company? An investigation on the consumer behavior in Facebook brand community. Telematics and Informatics, 32(4), 930-939.

Hsu, C.-P., Chiang, Y.-F., \& Huang, H.-C. (2012). How experience-driven community identification generates trust and engagement. Online Information Review, 36(1), 72-88.

Hsu, Y.-L. (2012). Facebook as international eMarketing strategy of Taiwan hotel. International Journal of Hospitality Management, 31(3), 972-980. 
Iwasaki, Y., \& Havitz, M. E. (1998). A path-analytic model of the relationship between involvement, psychological commitment, and loyalty. Journal of Leisure Research, 30(2), 337-347.

Jeong, H.-J., \& Koo, D.-M. (2015). Combined effects of valence and attributes of e-WOM on consumer judgment for message and product: The moderating effect of brand community type. Internet Research, 25(1), 2-29.

Keng, C. J., Ting, H. Y., \& Chen, Y. T. (2011). Effects of virtual-experience combinations on consumerrelated sense of virtual community. Internet Research, 21(4), 408-834.

Lin, Y. H. (2015). Innovation brand experience's influence on brand equity and brand satisfaction. Journal of Business Research, 68, 2254-2259.

Luo, Q., \& Zhang, H. (2016). Building interpersonal trust in a travel-related virtual community: A case study on a Guangzhou couchsurfing community. Tourism Management, 54, 107-121.

Matzler, K., Grabner-Krauter, S., \& Bidmon, S. (2008). Risk aversion and brand loyalty: The mediating role of brand trust and brand affect. Journal of Product \& Brand Management, 17(3), 154-162.

McAlexander, J. H., Schouten, J. W., \& JKoenig, H. F. (2002). Building Brand Community. Journal of Marketing, 66(1), 38-54.

McKnight, D. H., Choundhury, V., \& Kacmar, C. (2002). The Impact of Initial Consumer Trust on Intentions to Transact With a Website: A Trust Building Model. Journal of Strategic Information System, 11, 297-323.

McMillan, D. W., \& Chavis, D. M. (1986). Sense of community: a definition and theory. Journal of Community Psychology, 14(1), 6-23.

Morgan, R. M., \& Hunt, S. D. (1994). The Commitment-Trust Theory of Relationship Marketing. Journal of Marketing, 58, 20-38.

Mukherjee, A., \& Nath, P. (2007). Role of Electronic Trust in Online Retailing: A Re-Examination of the Commitment-Trust Theory. European Journal of Marketing, 41(9/10), 1173-1202.

Muniz, A. M., \& O'guinn, T. C. (2001). Their ethnographic study identified the presence of the three traditional markers of community. Journal of Consumer Research, 27(4), 412-432

Nambisan, P., \& Watt, J. H. (2011). Managing customer experiences in online product communities. Journal of Business Research, 64(8), 889-895.

Obada, D. R. (2014). Online flow experience and perceived quality of a brand website: InPascani.ro Case Study. Procedia-Social and Behavioral Sciences, 149, 673-679.

Oliver, R., \& Rust, R. (1997). Customer Delight: Foundation, Finding, and Managerial Insight. Journal of Retailing, 73(3), 311-337.

Oliver, R. L. (1999). Whence Consumer Loyalty? Journal of Marketing, 63((special issue)), 33-34.

Petrovčič, A., Petrič, G., \& Manfreda, K. L. (2016). The effect of email invitation elements on response rate in a web survey within an online community. Computers in Human Behavior, 56, 320-329.

Ribbink, D., van Riel, A. C. R., Liljander, V., \& Streukens, S. (2004). Comford Your Online Customer: Quality, Trust, And Loyalty on Internet. Managing Service Quality, 14(6), 446-456.

Ruparelia, N., White, L., \& Hughes, K. (2010). Drivers of brand trust in internet retailing. Journal of Product $\mathcal{E}$ Brand Management, 19(4), 250-260.

Sahin, A., Zehir, C., \& Kitapci, H. (2011). The Effects of Brand Experiences, Trust and Satisfaction on Building Brand Loyalty; An Empirical Research On Global Brands. Procedia-Social and Behavioral Sciences, 24, 1288-1301.

Solomon, R. C., \& Flores, F. (2001). Building trust in business, politics, relationships, and life. Oxford: Oxford University Press.

Samu, S., Lyndem, P. K., \& Litz, R. A. (2012). Impact of brand-building activities and retailer-based brand equity on retailer brand communities. European Journal of Marketing, 46(11/12), 1581-1601.

Shang, R.-A., Chen, Y.-C., \& Liao, H.-J. (2006). The value of participation in virtual consumer communities on brand loyalty. Internet Research, 16(4), 398-418.

Singh, J., \& Sirdeshmukh, D. (2000). Agency and trust mechanisms in consumer satisfaction and loyalty judgments. Journal of the Academy of Marketing Science, 28(1), 150-167.

Tanrikulu, Z., \& Celilbatur, N. (2013). Trust Factor Affectng E-Ticket Purchasing. Procedia-Social and Behavioral Sciences, 73, 115-119. 
Wang, Y., Ma, S. S., \& Li, D. (2015). Customer participation in virtual brand communities: The selfconstrual perspective. Information $\mathcal{E}$ Management, 52(5), 577-587.

Wu, J., Huang, L., Zhao, J. L., \& Hua, Z. (2015). The deeper, the better? Effect of online brand community activity on customer purchase frequency. Information $\mathcal{E}$ Management, 52(7), 813-823.

Yoo, C. W., Sanders, G. L., \& Moon, J. (2013). Exploring the effect of e-WOM participation on e-Loyalty in e-commerce. Decision Support Systems, Article in Press, 1-10. 